\title{
Examining water quality in the Chesapeake Bay: A hands-on sustainability activity for 5th to 7 th graders
}

Dr. Bradley A. Striebig, James Madison University

Dr. Striebig is a founding faculty member and first full professor in the Department of Engineering at James Madison University. Dr. Striebig came to the JMU School of from Gonzaga University where he developed the WATER program in cooperation with other faculty members. Dr. Striebig is also the former Head of the Environmental Technology Group at Penn State's Applied Research Laboratory. In addition to Dr' Striebig's engineering work, he is also a published freelance photographer who has works with local and international NGOs. Dr. Striebig was the founding editor of the Journal of Engineering for Sustainable Development and an assistant editor for the Journal of Green Building.

Dr. Stephen Keith Holland, James Madison University 


\section{Examining water quality in the Chesapeake Bay: A hands-on sustainability activity for $5^{\text {th }}$ to $7^{\text {th }}$ graders}

A "Green Techfacturing" three-day camp for middle school students to promote awareness of sustainability and STEM education was conducted during the summers of 2012 and 2013. The camp included half-day hands-on learning activities and half-day field trips to local manufacturing facilities. The principles of green engineering that have been implemented in local facilities are emphasized during these facility tours. This paper will discuss and demonstrate how the Chesapeake Bay Foundation's water report card is used to discuss water resource issues and hands-on learning experiences that teach students about their water footprint, water quality and sustainable water use.

Hands on Activities included: the review of local water quality reports; discussion of local and global water resources; review of regional water quality issues in the Chesapeake Bay watershed; field testing dissolved oxygen levels, $\mathrm{pH}$, and nutrient levels in a local body of water; a field trip to a wastewater treatment facility; and student presentations about their learning experiences. The proposed demonstration will show how middle school age students conducted water testing in a local water body and compared their results to the Chesapeake Bay Foundation's "Report Card" on water quality in the Bay. Students were given 10 question sustainability surveys prior to and after completion of the camp to demonstrate and assess camp objectives.

\section{Background}

There is a concerted effort to encourage young women and men to consider pursuing higher education and careers in the STEM fields. A community-college and university collaboration was created to develop a summer program that exposed rising sixth- to rising eighth-grade students to concepts in Science, Technology, Engineering and Math.

Students participated in three-days of hands-on activities designed to give them an awareness of the opportunities in science and engineering. The program was designed and facilitated through a partnership by community college instructors, university instructors, outreach staff, and local industrial representatives.

The Green Techfacturing day camp was offered at no cost to participants. This was a grantfunded program sponsored by the Shenandoah Valley Energy Partnership (SVEP) through the Shenandoah Valley Workforce Investment Board (SVWIB) and local industries. The long-term grant goal was to encourage a local workforce with skills in sustainable construction, weatherization, manufacturing, building design and renewable energy industries. The Green Techfacturing day camp was focused on using technology and engineering to increase efficiency and sustainability.

The camp was designed for participants to explore four specific areas of STEM: engineering and technology tools (such as Computer Aided Drawing and 3-D modeling), energy resources, 
environmental science, and mechanical wind energy. There was an average of 98 students enrolled in the camp each year. Over the four-year period more than $50 \%$ of the participants returned for a second year of the camp, since the camp was designed to allow students to explore 2 of the above areas each year. Every year there were twenty-four new participants for each concentration of the camp. (It would take a participant two-years to complete both areas of concentration.) This paper specifically addresses the experience designed to expose participants to environmental science. Each day of the camp, students participated in an experiential learning lab and toured a local manufacturing facility to witness STEM concepts in practice, meet scientist and engineers working in local industrial facilities, and gain insights into the variety of local STEM related employment opportunities. A sample participant schedule outlining the daily activities for a student exploring environmental science and energy resources is shown in Table 1.

Table 1: Sample participant schedule for Green Techfacturing three-day camp.

\begin{tabular}{|l|l|l|}
\hline \multicolumn{1}{|c|}{ Day } & \multicolumn{1}{|c|}{ Timing } & \multicolumn{1}{c|}{ Activity } \\
\hline 1 & Early morning & $\begin{array}{l}\text { Check-in } \\
\text { Introductions } \\
\text { Describe "green" manufacturing }\end{array}$ \\
\cline { 2 - 3 } & Late morning & $\begin{array}{l}\text { Tour facility with renewable biofuel power plant, solvent } \\
\text { recovery and reuse, and wastewater treatment }\end{array}$ \\
\cline { 2 - 3 } & Early Afternoon & $\begin{array}{l}\text { Environmental Science Project at University Pond and } \\
\text { Arboretum }\end{array}$ \\
\cline { 2 - 3 } & Late Afternoon & $\begin{array}{l}\text { Discussion of days learning activities } \\
\text { Review } \\
\text { Dismissal }\end{array}$ \\
\hline 2 & Early morning & $\begin{array}{l}\text { Check-in } \\
\text { Review "green" manufacturing } \\
\text { Personal ecological footprint analysis }\end{array}$ \\
\cline { 2 - 4 } & Late morning & $\begin{array}{l}\text { Solar panel activity to describe energy consumption, energy } \\
\text { measurement, and units of energy }\end{array}$ \\
\cline { 2 - 4 } & Early Afternoon & $\begin{array}{l}\text { Tour facility with reuse of metal packaging plant with reuse and } \\
\text { recycling of metals }\end{array}$ \\
\cline { 2 - 4 } & Late Afternoon & $\begin{array}{l}\text { Discussion of days learning activities } \\
\text { Review } \\
\text { Dismissal }\end{array}$ \\
\hline 3 & Early morning & $\begin{array}{l}\text { Groups meet in computer laboratory or classroom to develop a } \\
\text { multimedia presentation describing what they leaned during the } \\
\text { camp }\end{array}$ \\
\cline { 2 - 3 } & Late morning & $\begin{array}{l}\text { Groups present to parents } \\
\text { Social meeting }\end{array}$ \\
\cline { 2 - 3 } & Lismissal \\
\cline { 2 - 3 } & Late Afternoon & \\
\hline
\end{tabular}


Introducing sustainability concepts

The instructors relied heavily on the educational materials generated by several organizations for content for introducing the concepts of sustainability. In particular, the "Living Planet Report" provided excellent graphics and illustrations to introduce the concepts of resources, population, consumption and biocapacity (WWF 2012). These general concepts were introduced and discussed in a large group setting, with small group discussions used to encourage participants to develop their own questions about sustainability in an inquiry based learning process.

The concept introduction was followed by an activity, where participants in small groups had to determine their environmental footprint using an online ecological footprint calculator (Ewing et. al. 2010). This ecological footprint calculator uses national footprint data and a simple sliding scale input process to generate a step-by step illustrated ecological footprint. Furthermore the final information presented includes an estimate of the number of planets required for a given lifestyle and methods that an individual can take to reduce their ecological footprint. In addition to calculating their ecological footprint, campers were also guided to explore methods for modifying their impact results and discover the primary factors that impact the ecological footprint assessment. Through this activity, they gained an understanding of the roles that societal infrastructure, transportation, water consumption habits, food consumption habits, consumer habits, and energy use patterns play in determining one's ecological footprint.

The next sections detail the camp event presented in Table 1.

Day 1 - First manufacturing facility tour

After the brief introductory session to define resources, consumption and sustainability, participants traveled to a nearby manufacturing facility. Stat-of-the-art resource recovery and reuse processes are explored at this facility. Participants have a chance to tour the facility and ask engineers and scientists about the work they are doing and learn about career paths in science and technology.

Sustainable processes described during the tour include: biological processes in manufacturing, solvent recovery and reuse, steam and energy production with biofuels and wastewater treatment. The instructors and guides pay special attention to noting avoidance and minimization of environmental impacts, economic impacts and social impacts of the goods and processes at the manufacturing facility. Participants are also introduced to water quality parameters and measurements at the facility's wastewater treatment plant, in order to transition to the afternoon's activities.

Day 1 - Hands-on water quality investigation

Following the morning manufacturing facility tour, participants are introduced to water quality issues in the afternoon. The camp lies within the Chesapeake Bay Watershed, and most participants and families live within this watershed. The Chesapeake Bay Foundation (CBF) does an excellent job of articulating water quality issues and impacts in their "State of the Bay Report" (CBF 2010). Students are asked about water quality issues in the area, and then compare 
their presumptions to the information presented in the CBF "Report Card" which correlates water quality parameters to an A, B, C, D or F school grade for three categories: pollution, habitat, and fisheries.

Instructors and participants are then able to explore the concepts of sustainability in relationship to these categories. The fisheries category is used to relate the concepts of population, resources and consumption to rockfish, oysters, crab and shad populations in the watershed and Bay. The habitat is used to discuss land use, and development and the relationship between land use and environmental impacts, which leads into the pollutants in the watershed. Instructors help by providing definitions of the pollutant categories shown in the report card, which include: nitrogen/phosphorus, dissolved oxygen, water clarity, and toxics.

Participants work with instructors and college student/teaching assistants to measure several of theses parameters at the University's Arboretum pond. Because this activity takes place on a summer afternoon, and the pond is home to numerous fish and waterfowl, the water quality is generally marginal, which is well-suited for the purposes of the program. Participants perform the following tests at several test "stations" using Hach water quality kits to determine the following water related parameters (Hach 2012):

- Disolved oxygen,

- Nitrate

- Phosphorus (reactive)

- $\mathrm{pH}$

- Turbidity

- Hydrogen-sulfide producing bacteria

Participants compare the data they have collected to the information presented in the CBF water quality report card and the instructors also introduce the local water quality report from the water service provider to the students. This allows for discussion of drinking water quality and water use in the home.

\section{Day 2 - Energy use activities}

On the second day of the camp, a brief discussion of the previous day's activities and observations is held. Using a computer laboratory facility, participants are then guided through the use of an online ecological footprint estimator (Ewing et. al. 2010). The ecological footprint estimates are compared amongst the participants and a discussion about the factors that influence the ecological footprint are held. Campers are then provided an opportunity to experiment with different calculator inputs to explore how the footprint estimate changes based on personal behaviors.

From the ecological footprint activity, participants observe that, for individuals in the United States, a significant contributor to the large ecological footprint values is energy consumption. This discovery serves at the impetus for exploring energy generation and consumption. 
Campers are first introduced to basic electrical energy concepts through the use of a power supply connected to a small incandescent light bulb. Voltmeters and ammeters are used to quantify power consumption in relation to light output. Participants are then challenged to use small solar panels to generate the power required to light the incandescent light. Through experimentation, campers explore how the total solar panel area, different connection configurations (series vs. parallel), solar alignment, shading, and cloud cover impact the power delivered by the photovoltaic cells. Energy units and scales of energy production are also discussed through these activities.

The exploration activity culminates with participants estimating the land area required by commercial photovoltaic technologies to meet their personal daily energy demands. This area is illustrated visually by having the students measure and mark this area in an open field area.

Day 2 - Second manufacturing facility tour

In the second afternoon, participants tour a different manufacturing facility, interact with engineers and scientists about the work they are doing and learn about career paths in science and technology.

Sustainable processes described during the tour include material recovery and reuse, energy production and energy conservation measures. The instructors and guides pay special attention to noting energy and material consumption and conservation methods at the manufacturing facility. The concept of embedded energy is discussed with participants following the tour.

Participant assessment activities

The third day of the camp, participants review the information they learned throughout the previous two days. Student groups use Powerpoint or Presi to storyboard a presentation or skit to summarize the information from camp. The morning is spent reviewing and developing the student's skits and presentations with teaching assistants. The participant's assessments are given at this time. The parents of the participants are invited to attend these presentations. After the presentations, camp participants and parents are asked to provide feedback about the camp program. Time is set aside for additional queries and discussion about academic and career paths in science and technology.

\section{Assessment results}

Assessment methods reported herein are based on short selected questions the instructors felt would be representative of the broad themes of the camp, as well as a few specific questions to gauge the depth of understanding in specific areas which may be addressed in future iterations of the green Techfacturing camp. Students were asked the following eight questions about sustainability concepts:

- How many Earths would be required is everyone on earth enjoyed your lifestyle?

- How many planets would be required if everyone on earth consumed the same resources as someone living in South Africa? 
- Which of these activates consume energy, food, or water?

- How much total energy do you think an average person living in the US consumes each day?

- What units are used to measure energy?

- How much food do you think an average person living in the US consumes each day?

- How much water do you think an average person living in the US consumes each day?

- What things can be measured to determine if water is safe for fishing and recreation?

An additional question was asked about participant's attitude toward resource availability in the future:

- Do you think kids born 50 years from now should be able to enjoy the same resources you use today?

The results of the assessment questions are shown in Figure 1.

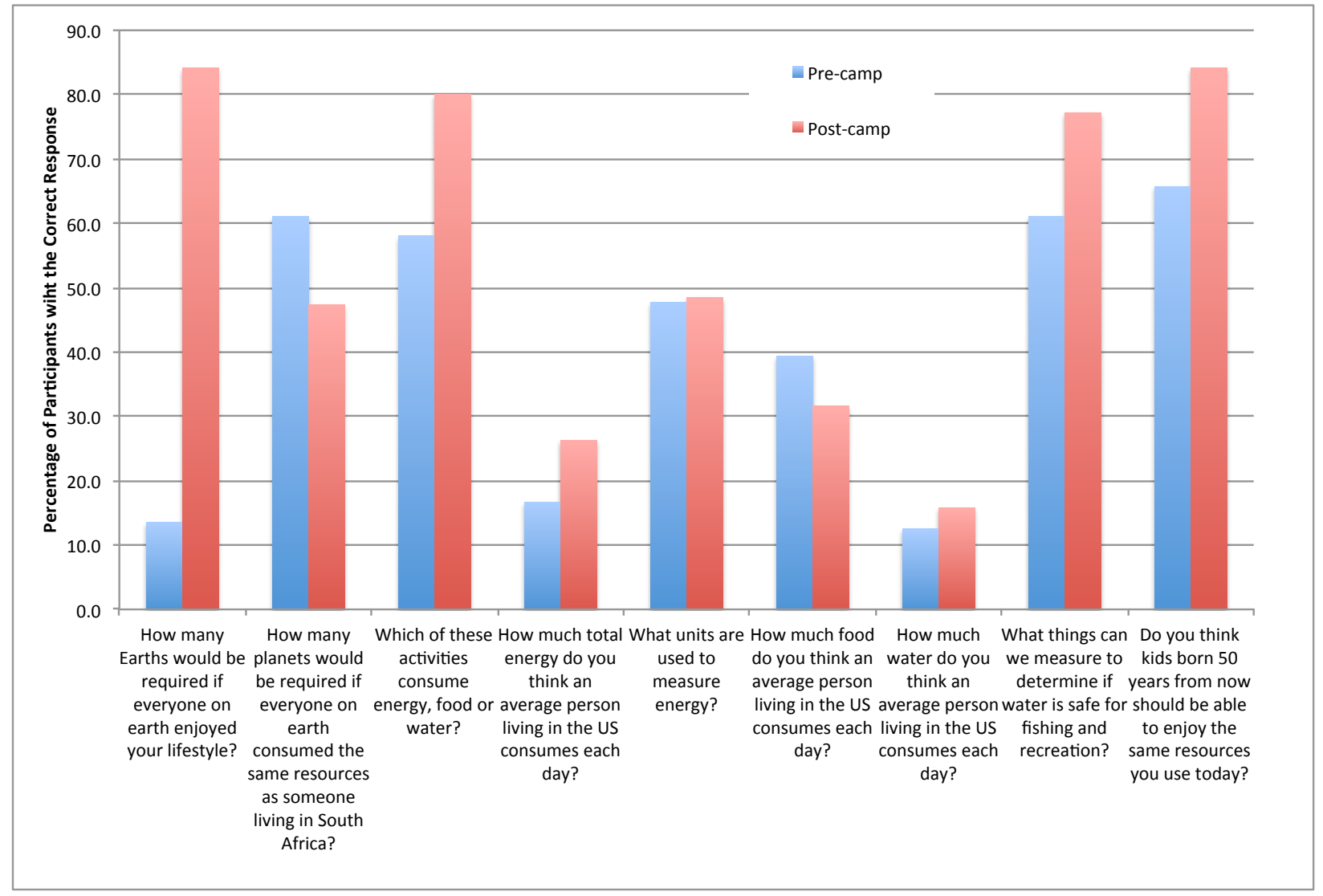

Figure 1. Pre- and Post-camp responses to sustainably awareness and assessment questions.

The limited assessment data collected to date, shown in Figure 1, illustrates that participants were more aware of the broad concepts in sustainability such as consumption and one's ecological footprint after the camp experience. Participants also had a better understanding of what type of water quality parameters could be measured to provide and indication of water 
quality impacts in the Chesapeake Bay. As one might expect, these questions are closely linked to specific activities in the camp designed to promote this awareness, including the facility tours, the ecological footprint calculator and water quality measurement experiences.

The specifics of the discussion were difficult for students to be able to rearticulate during the three-day camp. Questions asking about specific quantities and comparisons to other countries remain difficult for the middle-school age group.

Future iterations of the camp may include additional activities involving the exploration of energy units and values. The concepts of energy usage and valuation is difficult for much of the population, it is straightforward to use a ruler to measure an inch or a meter; however the Watt, calorie and BTU are much more difficult concepts to understand, and thus energy utilization and consumption remains a challenging aspect of explaining sustainability strategies.

Finally, the instructors were curious about participant's intergenerational notions about resources and sustainability. Nearly all definitions of sustainability include an intergenerational component of resource availability. The dramatic change in the awareness about the number of Earths needed for their current lifestyle and a measurable increase in the number of participants that feel intergenerational resources availability should be equitable potentially illustrates the linkage between consumption, resource use, impacts, and intergenerational sustainability is of importance and interest to this group of middle-school age participants.

\section{Instructor resources}

Chesapeake Bay Foundation. 2010. State of the Bay Report. Chesapeake Bay Foundation, Annapolis, MD.

Ewing B., A. Reed, A. Galli, J. Kitzes, and M. Wackernagel. 2010. Calculation Methodology for the National Footprint Accounts, 2010 Edition. Oakland: Global Footprint Network.

Hach. 2012. Nitrate, low-range. Method 8507.

Hach. 2012. Nitrate, mid-range. Method 8171.

Hach. 2012. Oxygen, Dissolved. Method 10360.

Hach. 2012. pH. Method 8156.

Hach. 2012. Phosphorus, reactive. Method 8048.

Kemp, W.M., Boynton, W.R., Adolf, J.E., Boesch, D.F., Boicourt, W.C., Brush, G., Cornwell, J.C., Fisher, T.R., Glibert, P.M., Hagy, J.D., Harding, L.W., Houde, E.D., Kimmel, D.G., Miller, W.D., Newell, R.I.E., Roman, M.R., Smith, E.M., Stevenson, J.C. 2005. Eutrophication of Chesapeake Bay: historical trends and ecological interactions. Mar Ecol Prog Ser. 303: 1-29. 
Wick, C., Jasinski, D., Longstaff, B. 2007. Breath of Life: Dissolved Oxygen in the Chesapeake Bay. A newsletter from the Chesapeake Bay Program.

USEPE. 2001. Ambient Water Quality Criteria for Dissolved Oxygen, Water Clarity and Chlorophyll a for the Chesapeake Bay and Its Tidal Tributaries. Office of Water/Office of Science and Technology, Washington DC. EPA 903-R-03-002.

WWF. 2012. Living Planet Report 2012. WWF International, Gland, Switzerland. 